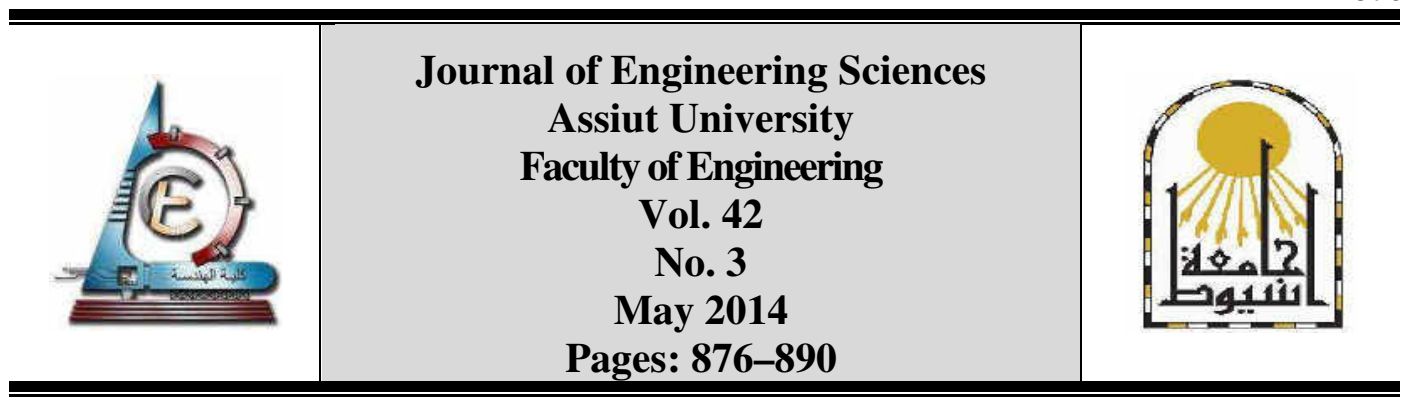

\title{
AN EXPERIMENTAL STUDY ON THE AVAILABILITY OF SOLID WASTE OF MINES AND QUARRIES AS COARSE AGGREGATE IN CONCRETE MIXES
}

\author{
Ahmed Abdul Mageed Ahmed ${ }^{* 1}$, Khairy Hassan Abdel kareem ${ }^{2}$, \\ Ahmed Mohamed Altohamy ${ }^{3}$ and Sherein Ahmed Mohamed Rizk ${ }^{4}$ \\ ${ }^{1}$ Prof.of Mineral Processing, Assiut univ., Faculty of Eng., Mining and Metal. Dept. \\ ${ }^{2}$ Prof. of concrete structures, Assiut univ., Faculty of Eng., Civil Dept. \\ ${ }^{3}$ Assistant Prof. of Soil and Foundation, Beni -Suef univ., Faculty of Eng., Civil Dept. \\ ${ }^{4}$ Assistant lecturer, Ph.D. researcher, Beni-Suef univ., Faculty of Eng., Civil Dept.
}

Received 11 February 2014; revised 26 February 2014; accepted 22 March 2014

\begin{abstract}
In Egypt, large quantities of coarse solid wastes are generated during the processing of phosphate ores and quarrying operations of marble and granite rocks. These solid wastes are stored in piles around or near mine sites, which cause many environmental problems. Various solutions have been sought for this major environmental problem and the best solution found is recycling. However these wastes, because of their similarity to the natural aggregate, represent a potentially useful source of material for a variety of applications.

The main purpose of this research is to investigate the possibility of utilizing over screen reject generated during phosphate ore processing and rock fragments of quarrying marble and granite rocks in concrete production as full replacement of natural gravel in concrete mix. A number of tests were carried out on these wastes to determine their physical, mechanical and chemical properties, according to the ECP 203 of natural aggregate. So, concrete mixes using the above mentioned wastes as coarse aggregate were done, and then tests for fresh and hardened concrete were carried out. The mean value of uniaxial compressive strength of standard concrete cubes after 28 days of curing was found to be in order of $193 \mathrm{Kg} / \mathrm{cm}^{2}$ for phosphate waste, $262 \mathrm{~kg} / \mathrm{cm}^{2}$ for marble waste, and $272 \mathrm{~kg} / \mathrm{cm}^{2}$ for granite waste, which approach the conventional concrete used in building. The obtained results proved that these kinds of wastes can be used for concrete mix in civil construction. Admixtures may be used to improve the strength of the first one. The positive uses of these wastes are considered beneficial from the economic and environmental points of view.
\end{abstract}

Keywords: Phosphate processing wastes, Marble aggregate, Granite aggregate, Aggregate for civil constructions, Environmental cleaning, Mechanical and chemical properties.

\footnotetext{
* Corresponding author.

E mail address: mageed52005@gmail.com
} 


\section{Introduction}

Aggregates for concrete production, occupy $70-80 \%$ of its volume, where coarse aggregates are the larger part of about $60 \%$ of the total volume of aggregates [1-3]. The civil engineering construction industry is believed to be one of the most potential consumers of mineral resources, thus deposits of natural gravel, especially those located too close to major urban centers are getting depleted and becoming costly as a result of transportation costs and environmental restrictions [4-5]. At the same time, the problem of disposing and managing solid wastes generated from mineral processing plants and quarries has become one of the major environmental, economical and social issues [6]. Leaving the waste materials to the environment directly can cause many environmental problems. Hence, many countries have been working on how to re-use the waste materials to reduce hazards to the environment [7-9]. Three main areas may be identified as being the most successful ones with respect to utilization of mining and quarrying waste. These are civil engineering, road construction and building materials production $[8,10]$.

The possibility of using solid wastes materials as coarse aggregate in concrete has got increasing attention in recent years as one promising solution to reduce solid waste problems [1, 3, 8, 11-12]. The use of solid waste, in construction in general and concrete mix in particulate, is not a new concept. Industrial wastes for example are the basis of many concrete admixtures, fly ash has been used as pozzolanic substance in concrete for several decades, and blast furnace slags have been used as aggregates and as a cementitious material [3, 12]. Also granulated waste plastic, glass, and fiberglass waste materials, marble, limestone and granite dusts were used to partially substitute the fine aggregates (sand) in concrete composites [3,6,9,12-15]. The use of concrete for the disposal of solid wastes has focused mostly on service as aggregates, since this provides the only real potential for the utilization of larger quantities of waste materials.

Aggregate materials, extracted mainly from coarse mill rejects of ore processing and via quarrying operations of marble, granite, basalt and limestone rocks can be used as alternative resources to substitute natural coarse aggregate (natural gravel) in concrete production.

In Egypt, there are huge accumulations of over screen reject (more than 7 million tons), generated as a result of phosphate ore processing at El Nasr mining company, Sebaeya, Egypt. Also, large quantities of rock fragments are produced as by-product due to crushing bad qualities blocks during extraction and hauling of marble and granite blocks. These solid wastes are stored in piles around or near to mineral processing plant and quarry sites, which cause many environmental problems and must be removed.

Recycling wastes as useful materials is very important environmental management tool for achieving a sustainable development as well as the land becomes available for reuse. On the other hand, recycling of these solid wastes without properly based scientific research can result in development problems greater than the waste itself [16].

The main goal of this study is to evaluate the possibility of full replacement of natural gravel in concrete production with alternative resources of coarse aggregate generated from phosphate processing, quarrying marble and granite rocks. Possibility of utilization of these wastes in concrete mix is an attractive alternative for their disposal, because disposal costs and pollution problems are reduced. Also the natural resources are conserved. 
In order to evaluate the waste materials for their suitability in concrete mix, it is important to assess their physical, chemical and mechanical properties.

\section{Experimental work}

\subsection{Materials}

The materials used in the production of concrete are Portland cement, water, fine aggregate and coarse aggregate.

\subsubsection{Cement}

Ordinary Portland cement, its properties are agreed with ECP 203 [28].

\subsubsection{Water}

Tap water is used.

\subsubsection{Fine aggregate}

Natural sand of size less than $5 \mathrm{~mm}$, its properties are agree with ECP 203 [28].

\subsubsection{Coarse aggregate}

Three types of recycled wastes were used in this study. The main source of these aggregates is El-Nasr mining company at Sebaeya, Egypt. The first one is over screen rejects of phosphate ore processing. The second and third types of aggregate are rock fragments of refused marble and granite blocks. The three aggregate samples were crushed with a nominal size of $20 \mathrm{~mm}$ as specified by some investigators [4,17-18] to be suitable for casting cubes of $10 * 10 * 10 \mathrm{~cm}$ and beams of $10 * 10 * 50 \mathrm{~cm}$. The crushed product is thoroughly mixed and spitted into batches each of $25 \mathrm{~kg}$ by coning and quartering. The pictures of the crushed aggregate used in this work are shown in Figure 1.

The origin of phosphate wastes are sedimentary rocks and consists mainly of hard phosphate particles cemented with siliceous materials. The Crushed marble origin is metamorphic rocks and consists mainly of calcite and dolomite with fine crystalline grains, and the crushed granite is an intrusive volcanic rock (igneous rocks) consists mainly of orthoclase, quartz and mica with coarse crystalline grains.

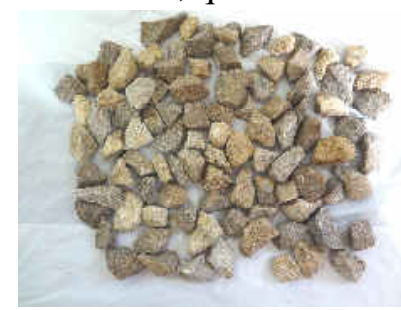

(a)

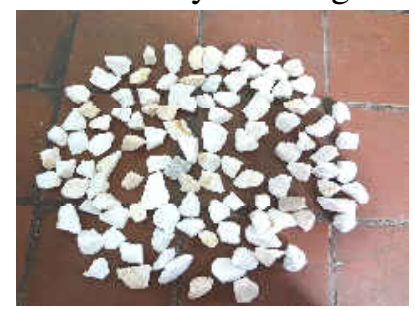

(b)

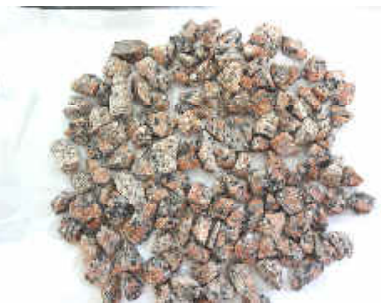

(c)

Fig. 1. Crushed aggregates used in this study, (a) phosphate, (b) marble, (c) granite.

\subsection{Procedures}

Aggregates strongly influence the properties of hardened concrete, especially the mechanical properties. Consequently, selection of aggregates is an important process [19]. Although some variations in aggregate properties are expected, the most important aggregate quality tests are: 


\subsubsection{Physical properties}

Such as particle shape, specific gravity, grading, water absorption, voids in coarse aggregates, surface area, fineness modulus and deleterious substances (dust coating, clay and silt, etc.). Details of the tests procedures are well known and published elsewhere [20-22].

\subsubsection{Grading of aggregates}

The used set of sieves for coarse aggregate is considered of 20,10 and $5 \mathrm{~mm}$, and for fine aggregates (natural sand) is consisted of $5,2.5,1.25,0.630,0.315$ and $0.160 \mathrm{~mm}$. The test procedure is given elsewhere [20-21, 23-24].

\subsubsection{Chemical properties}

Such as chlorine ion percent $\left(\mathrm{CL}^{-}\right)$, sulfate content $\left(\mathrm{SO}_{3}\right)$, soundness test and alkalinity. The test procedures of the chemical properties are given in details in reference [17,22].

\subsubsection{Mechanical properties}

The most important mechanical properties are:

\subsubsection{Aggregate crushing strength (AC)}

The coarse aggregates used in concrete production should be strong enough to withstand heavy loads. Apparatus and test procedure for this purpose are given in reference [20,22-23].

\subsubsection{Aggregate impact value (AIV)}

The AIV test is used to determine the effects of shock and impact on the coarse aggregates. Procedures of this test are given in details in references [18, 22].

\subsubsection{Los Angles abrasion value (LAV)}

This test is an accepted measure of the hardness property of coarse aggregates. The apparatus and procedure of the test are given elsewhere [22-23].

\subsubsection{Aggregate slake durability index $\left(I d_{2}\right)$}

It measures the aggregate durability (resistance to weathering). The apparatus and test procedures are given in details in references [24, 25].

\subsubsection{Concrete tests}

Three concrete mixes were prepared from crushed phosphate, marble and granite waste materials with ratio of 1:2:4 (cement: sand: coarse aggregate). The water to cement ratio of 0.5 was used for all mixes, extra water was sometimes added to increase the flow ability and workability of the concrete mix. Details about each mix proportions are given in Table 1 .

\section{Table 1.}

Concrete mix proportion.

\begin{tabular}{|c|c|c|c|c|c|c|}
\hline $\begin{array}{l}\text { Type of } \\
\text { waste }\end{array}$ & Material & $\begin{array}{l}\text { Ratio of each } \\
\text { material in } \\
\text { the mix by } \\
\text { weight }\end{array}$ & $\begin{array}{c}\text { Specific } \\
\text { gravity }\end{array}$ & $\begin{array}{c}\text { Absolute volume of } \\
\text { each material to make } 1 \\
\mathrm{~m}^{3} \text { of concrete }\end{array}$ & $\begin{array}{l}\text { Cal. wt. of } \\
\text { each } \\
\text { material } \\
(\mathrm{kg})\end{array}$ & $\begin{array}{l}\text { Practical wt. } \\
\text { of each } \\
\text { material } \\
(\mathrm{kg})\end{array}$ \\
\hline $\begin{array}{c}\text { Phosphate } \\
\text { waste }\end{array}$ & $\begin{array}{c}\text { Cement } \\
\text { Natural sand } \\
\text { Aggregate } \\
\text { W/C } \\
\text { Absorbed } \\
\text { water }\end{array}$ & $\begin{array}{c}1 \\
2 \\
4 \\
0.5 \\
0.054\end{array}$ & $\begin{array}{c}3.15 \\
2.6 \\
2.42 \\
1 \\
1\end{array}$ & $\begin{array}{c}(\mathrm{x} / 3.15) \\
(2 \mathrm{x} / 2.6) \\
(4 \mathrm{x} / 2.42) \\
0.5 \mathrm{x}\end{array}$ & $\begin{array}{c}309.0 \\
617.0 \\
1235.0 \\
154.0 \\
67.0\end{array}$ & $\begin{array}{c}300 \\
600 \\
1200 \\
150 \\
65\end{array}$ \\
\hline
\end{tabular}


JES, Assiut University, Faculty of Engineering, Vol. 42, No. 3, May 2014 , pp. 876-890

\begin{tabular}{|c|c|c|c|c|c|c|}
\hline $\begin{array}{l}\text { Type of } \\
\text { waste }\end{array}$ & Material & $\begin{array}{l}\text { Ratio of each } \\
\text { material in } \\
\text { the mix by } \\
\text { weight }\end{array}$ & $\begin{array}{c}\text { Specific } \\
\text { gravity }\end{array}$ & $\begin{array}{l}\text { Absolute volume of } \\
\text { each material to make } 1 \\
\mathrm{~m}^{3} \text { of concrete }\end{array}$ & $\begin{array}{l}\text { Cal. wt. of } \\
\text { each } \\
\text { material } \\
(\mathrm{kg})\end{array}$ & $\begin{array}{l}\text { Practical wt. } \\
\text { of each } \\
\text { material } \\
(\mathrm{kg})\end{array}$ \\
\hline & & & & $\begin{array}{c}3.24 \mathrm{x}=1000 \text { litter } \\
X=308.64\end{array}$ & & \\
\hline \multirow[t]{2}{*}{$\begin{array}{l}\text { Marble } \\
\text { waste }\end{array}$} & $\begin{array}{c}\text { Cement } \\
\text { Natural sand } \\
\text { Aggregate } \\
\text { W/C } \\
\text { Absorbed } \\
\text { water }\end{array}$ & $\begin{array}{c}1 \\
2 \\
4 \\
0.5 \\
0.004\end{array}$ & $\begin{array}{c}3.15 \\
2.6 \\
2.62 \\
1 \\
1\end{array}$ & $\begin{array}{c}(\mathrm{x} / 3.15) \\
(2 \mathrm{x} / 2.6) \\
(4 \mathrm{x} / 2.62) \\
0.5 \mathrm{x}\end{array}$ & $\begin{array}{c}322.0 \\
643.0 \\
1286.0 \\
161.0 \\
5.0\end{array}$ & $\begin{array}{c}300 \\
600 \\
1200 \\
150 \\
5\end{array}$ \\
\hline & & & & $\begin{array}{c}3.11=1000 \text { litter } \\
X=321.54\end{array}$ & & \\
\hline \multirow[t]{2}{*}{$\begin{array}{l}\text { Granite } \\
\text { waste }\end{array}$} & $\begin{array}{c}\text { Cement } \\
\text { Natural sand } \\
\text { Aggregate } \\
\text { W/C } \\
\text { Absorbed } \\
\text { water }\end{array}$ & $\begin{array}{c}1 \\
2 \\
4 \\
0.5 \\
0.003\end{array}$ & $\begin{array}{c}3.15 \\
2.6 \\
2.63 \\
1 \\
1\end{array}$ & $\begin{array}{c}(\mathrm{x} / 3.15) \\
(2 \mathrm{x} / 2.6) \\
(4 \mathrm{x} / 2.63) \\
0.5 \mathrm{x}\end{array}$ & $\begin{array}{c}322.0 \\
643.0 \\
1286.0 \\
161.0 \\
4.0\end{array}$ & $\begin{array}{c}300 \\
600 \\
1200 \\
150 \\
4\end{array}$ \\
\hline & & & & $\begin{array}{c}3.11 \mathrm{x}=1000 \text { litter } \\
\mathrm{X}=321.54\end{array}$ & & \\
\hline
\end{tabular}

The fresh concretes were prepared using a 50 liter rotating pan type mixer, coarse aggregate and fine aggregate were first mixed inside the mixer. Further mixing was done with the addition of cement, and then water was added gradually and mixed until reaching a homogenous mixture. The entire mixing operation was completed within 5-6 minutes.

\subsubsection{Testing of fresh concrete}

The slump test was carried out using a standard slump cone directly after mixing process followed by measuring compacting factor using standard apparatus, as given in reference [22]

\subsubsection{Preparation of concrete specimens}

For the determination of compressive strength at 7, 14, 28 and 70 days twelve cubes of $10 * 10 * 10 \mathrm{~cm}$ were cast from the fresh concrete mix of the three types of waste aggregate used in this study. In addition six beams $10 * 10 * 50 \mathrm{~cm}$ were cast from each concrete mixture for the determination of the flexural strength of the concrete produced. After casting, the cubes and prisms were demolded after 24 hours and immersed completely into water for further curing until their testing dates. Mixing and casting procedures were performed in accordance with the ECP 203 for concrete testing [22, 26, and 27].

\subsubsection{Testing of hardened concrete}

The compressive strength of concrete is the most common measure for judging its quality. Uni-axial compressive strength was determined at aging periods of 7, 14, 28 and 70 days after casting.

Procedures of testing the cubes are given in references [17, 22, and 26]. The determination of the flexural strength of concrete were carried out as described in the Egyptian code [22], consists essentially of testing a plain concrete beam under symmetrical two-point loading applied at one-third-span points and center point loading. The flexural strength calculated is often referred to as the modulus of rapture. For accurate results, the modulus of rapture (MR) was measured for each type of concrete produced by the two 
methods of loading. For that, six prisms were tested after curing in water for 28 days. The test procedure was given in details in references [17, 18, and 22].

\section{Results and discussion}

Aggregate particles should be clean, hard, strong and durable. In order to evaluate the waste materials for their suitability as coarse aggregate in concrete mix, it is important to assess their physical, chemical and mechanical properties. The mandatory tests of concrete aggregates which have been studied in this research work include the following properties:

\subsection{Grading of aggregates}

Grading of aggregate is one of the common tests performed on the aggregates before using it for concrete mixes. The governing parameters of aggregate course or fine, are the fineness modulus and surface area. The obtained results for the grading of the three types aggregate used and natural sand for making concrete are given in Table 2. Based on this information, the fineness modulus (F.M) and specific surface area (S.A.) can be calculated [20]. The sieve analysis was carried out according to the ECP 203 of concrete aggregates [22].

It's clear from Table 2, that the grading of the four samples are within the limits of natural aggregates according to the ECP 203s [20, 22].

Table 2.

Grading of coarse and fine aggregate.

\begin{tabular}{|c|c|c|c|c|c|c|c|}
\hline & Phosphate & Marble & Granite & $\begin{array}{l}\text { Standard } \\
\text { values }\end{array}$ & \multicolumn{2}{|c|}{ Natural Sand } & $\begin{array}{c}\text { Standard } \\
\text { values }\end{array}$ \\
\hline $\begin{array}{c}\text { Sieve } \\
\text { opening } \\
(\mathrm{mm})\end{array}$ & Passing $\%$ & Passing $\%$ & Passing $\%$ & Passing \% & $\begin{array}{c}\text { Sieve } \\
\text { opening } \\
(\mathrm{mm})\end{array}$ & Passing \% & Passing \% \\
\hline 20 & 100 & 100 & 100 & $90-100$ & 5 & 100 & $90-100$ \\
\hline 10 & 33.82 & 31.36 & 34.12 & $30-60$ & 2.5 & 99.66 & $75-100$ \\
\hline 5 & 1.46 & 2.14 & 1.08 & $0-10$ & 1.25 & 84.8 & $55-90$ \\
\hline Pan & 0 & 0 & 0 & & 0.63 & 55.24 & $35-59$ \\
\hline & & & & & 0.31 & 18.18 & $8-30$ \\
\hline & & & & & 0.16 & 1.13 & $0-10$ \\
\hline & & & & & Pan & 0 & \\
\hline \multicolumn{8}{|c|}{ Properties related to gradation } \\
\hline Property & Phosphate & Marble & Granite & $\begin{array}{l}\text { Standard } \\
\text { values }\end{array}$ & \multicolumn{2}{|c|}{ Natural Sand } & $\begin{array}{c}\text { Standard } \\
\text { values }\end{array}$ \\
\hline $\begin{array}{l}\text { Fineness } \\
\text { modulus }\end{array}$ & 6.65 & 6.67 & 6.65 & $5-8$ & \multicolumn{2}{|c|}{2.41} & $2-3.75$ \\
\hline $\begin{array}{l}\text { Specific } \\
\text { surface } \\
\text { area } \\
\left(\mathrm{cm}^{2} / \mathrm{gm}\right)\end{array}$ & 3.36 & 3.07 & 3.07 & $2-5$ & \multicolumn{2}{|c|}{78.85} & $60-100$ \\
\hline $\begin{array}{l}\text { Type of } \\
\text { gradation }\end{array}$ & Graded & Graded & Graded & ----- & \multicolumn{2}{|c|}{ Medium } & ---- \\
\hline $\begin{array}{l}\text { Shape of } \\
\text { particles }\end{array}$ & Irregular & Angular & Angular & ----- & \multicolumn{2}{|c|}{----- } & ---- \\
\hline $\begin{array}{l}\text { Surface } \\
\text { texture }\end{array}$ & Rough & Smooth & Crystalline & ----- & \multicolumn{2}{|c|}{----- } & ---- \\
\hline
\end{tabular}


JES, Assiut University, Faculty of Engineering, Vol. 42, No. 3, May 2014 , pp. 876-890

\begin{tabular}{|c|c|c|c|c|c|c|}
\hline & Phosphate & Marble & Granite & $\begin{array}{c}\text { Standard } \\
\text { values }\end{array}$ & Natural Sand & $\begin{array}{c}\text { Standard } \\
\text { values }\end{array}$ \\
\hline $\begin{array}{c}\text { Angularit } \\
\text { y no. }\end{array}$ & 9.22 & 7.87 & 8.14 & $0-12$ & ---- & ---- \\
\hline $\begin{array}{c}\text { Angularit } \\
\text { y index }\end{array}$ & 2.38 & 2.18 & 2.22 & $1.05-2.62$ & --- & --- \\
\hline $\begin{array}{c}\text { Surface } \\
\text { factor } \\
\text { index }\end{array}$ & 0.3 & 0.299 & 0.301 & ---- & 1.15 & ---- \\
\hline
\end{tabular}

\subsection{Physical properties of aggregate}

The measured physical properties of the three coarse aggregates used in this study as well as the fine aggregate (sand) and their standard values of each property, whenever there are corresponding values, are summarized in Table 3. Results showed that most of the physical properties were within the range of standard specifications and matches the ECP 203s of natural aggregates [20, 21, and 23]. The results of physical properties of the three coarse aggregates used in this study have established that the investigated aggregates are a suitable material to be used as coarse aggregate in concrete production. Also, from Table 3, it is clear that, the phosphate waste presented the highest water absorption in opposition to marble and granite aggregates due to its geological formation.

\section{Table 3.}

Physical properties of the investigated aggregates.

\begin{tabular}{|l|c|c|c|c|c|}
\hline \multirow{2}{*}{\multicolumn{1}{|c}{ Test name }} & \multicolumn{5}{c|}{ Aggregate type } \\
\cline { 2 - 7 } & Phosphate & Marble & Granite & Sand & $\begin{array}{c}\text { Standard } \\
\text { Values* }\end{array}$ \\
\hline Flakiness index \% & $20.72 \%$ & $24.49 \%$ & $18.04 \%$ & --- & $<25 \%$ \\
\hline Elongation index (\%) & $19.85 \%$ & $22.73 \%$ & $18.48 \%$ & --- & $<25 \%$ \\
\hline Water absorption \% & $5.38 \%$ & $0.4 \%$ & $0.33 \%$ & --- & $0-2.5 \%$ \\
\hline Bulk density & 1.20 & 1.32 & 1.36 & 1.62 & --- \\
\hline Voids percent & $45.25 \%$ & $41.85 \%$ & $41.05 \%$ & 31.27 & --- \\
\hline Apparent specific gravity & 2.42 & 2.62 & 2.63 & 2.6 & $2.5-2.8$ \\
\hline Deleterious substances\% & 0.9 & 0.09 & 0.03 & --- & $<3 \%$ \\
\hline
\end{tabular}

* The standard values are taken from references [20, 21, 23, and 28].

\subsection{Mechanical properties of aggregates}

The mechanical properties of the investigated coarse aggregate samples used in this study are summarized in Table 4. The tests were carried out according to ECP 203 [28]. It is clear from Table 4 that all the mechanical properties of the samples were within the range of standard specifications and matches the Egyptian specifications of natural coarse aggregates [21, 22, and 23].

Considering the geological origin of these three waste materials used in this study (sedimentary, metamorphic and igneous respectively), their mechanical properties are given in Table 4 regarded of relatively good mechanical behavior and of regular aggregates of good quality, having little or no weathering at all. 


\section{Table 4.}

Mechanical properties of the investigated aggregates.

\begin{tabular}{|l|c|c|c|c|}
\hline \multirow{2}{*}{\multicolumn{1}{|c|}{ Test name }} & \multicolumn{4}{c|}{ Aggregate type } \\
\cline { 2 - 5 } & Phosphate & Granite & Marble & $\begin{array}{c}\text { Standard } \\
\text { values* }\end{array}$ \\
\hline Crushing value (ACV) \% & $23.27 \%$ & $20.87 \%$ & $18.8 \%$ & $<30 \%$ \\
Slake durability index $\left(\mathrm{Id}_{2}\right)$ & 97.85 & 99.44 & 99.31 & 100 \\
Los Angeles abrasion value (LAV) \% & $31.6 \%$ & $28.6 \%$ & $29.38 \%$ & $30-50 \%$ \\
Impact value \% (AIV) & $15.87 \%$ & $9.00 \%$ & $9.44 \%$ & $<30 \%$ \\
\hline
\end{tabular}

*The standard values are taken from references [20, 22, and 23].

\subsection{Chemical properties of aggregates}

The chemical properties of the three coarse samples and fine aggregate (sand) are summarized in Table 5. The chemical tests were carried out according to ECP 203 [28]. It is clear from Table 5 that the chemical properties of the tested samples are within the standard specifications and matches the Egyptian specifications of natural aggregates [17, 22, 23].

\section{Table 5.}

Chemical properties of the aggregates used in this study.

\begin{tabular}{|l|c|c|c|c|c|}
\hline \multirow{2}{*}{ Property } & \multicolumn{5}{|c|}{ Type of aggregate } \\
\cline { 2 - 6 } & Phosphate & Granite & Marble & Sand & $\begin{array}{c}\text { Standard } \\
\text { values* }\end{array}$ \\
\hline Soundness test \% & 9.39 & 2.51 & 0.71 & ---- & $<12 \%$ \\
Chlorine ion, wt,. \% & 0.006 & 0.0023 & 0.0049 & 0.028 & $<0.04 \%$ \\
Sulfate content, wt.\% & 0.116 & 0.00517 & 0.0071 & 0.056 & $<0.4 \%$ \\
PH & 7.46 & 7.67 & 8.7 & 7.7 & Alkaline \\
Organic impurities & 3.02 & 0.57 & 5.17 & 0.90 & --- \\
\hline
\end{tabular}

$*$ References [17, 22, 23].

Soundness test was carried out with sodium sulfate solution of specific gravity 1.15 to 1.17 as specified by ECP [22]. The three coarse aggregates tested having soundness value less than $12 \%$. The phosphate aggregates presented the highest soundness value than marble and granite aggregates because the last two are denser and more durable.

From the physical, mechanical and chemical results given in Tables 1 to 5, it is clear that all results matches the specifications of natural gravel and can be considered as suitable materials to be used as coarse aggregates in concrete mix to full replacement natural gravel.

\subsection{Fresh concrete results}

The slump value and compacting factor of the three fresh mixes made from the recycled materials used in this study are presented in Table 6 . 
JES, Assiut University, Faculty of Engineering, Vol. 42, No. 3, May 2014 , pp. 876-890

\section{Table 6.}

Slump and compacting factor results of various fresh concrete.

\begin{tabular}{|l|c|l|l|l|l|}
\hline $\begin{array}{c}\text { Type of coarse } \\
\text { aggregate used }\end{array}$ & $\begin{array}{c}\text { Slump, } \\
\mathrm{mm}\end{array}$ & $\begin{array}{c}\text { Type of } \\
\text { slump }\end{array}$ & $\begin{array}{c}\text { Compacting } \\
\text { Factor }\end{array}$ & $\begin{array}{c}\text { Degree of } \\
\text { workability }\end{array}$ & $\begin{array}{c}\text { Consistency } \\
\text { according to } \\
\text { slump }\end{array}$ \\
\hline Phosphate & $50 \mathrm{~mm}$ & True & 0.95 & Medium & Plastic \\
Marble & $75 \mathrm{~mm}$ & True & 0.94 & Medium & Plastic \\
Granite & $50 \mathrm{~mm}$ & True & 0.93 & Medium & Plastic \\
\hline
\end{tabular}

Concrete mix having slump value in range $50-100 \mathrm{~mm}$ are considered of medium workability and can be used in various applications [17, 18,22]. The values of compacting factor indicated that the produced concrete has a good flowing ability.

\subsection{Hardened concrete results}

Compressive strength: the compressive strength results of various concrete made with three recycled materials are given in Table 7. The results presented in the Table are the arithmetic mean of three tested cubes each of size $10 * 10 * 10 \mathrm{~cm}$, then the modified compressive strength which equivalent to standard cubes of size $15 * 15^{*} 15 \mathrm{~cm}$ can be calculated by multiplying the arithmetic mean value by $0.97[17,28]$.

In general the compressive strength values of concrete made from phosphate aggregates are showed a lower strength at 7,14, 28 and 70 days than those made from marble and granite of the same composition. This variation may be due to geological formation of each aggregate. In addition, the obtained results in Table 7 clearly indicate that with the progress time of curing, the strength attainment was improved in all the various concrete made from recycled materials studied.

Also it is observed from Table 7 that the compressive strength of concrete made with coarse marble aggregate approached that of the one made with granite. This may be attributed to the geological formation of marble as metamorphic rock deposited under high pressure, which gave it high strength and good properties. Figure 2 shows the failure shape of concrete cubes made with recycled aggregates during compression test.

\section{Table 7.}

Compressive strength results of concrete at different curing age.

\begin{tabular}{|l|c|c|c|c|c|c|}
\hline \multirow{2}{*}{$\begin{array}{l}\text { Curing } \\
\text { (days) }\end{array}$} & \multicolumn{5}{|c|}{$\begin{array}{c}\text { Uniaxial compressive strength of cubes } \\
\left(\mathrm{kg} / \mathrm{cm}^{2}\right)\end{array}$} \\
\hline \multirow{4}{*}{} & \multicolumn{2}{|c|}{$\begin{array}{c}\left(10^{3} \mathrm{~cm}\right) \\
\text { Phosphate aggregate }\end{array}$} & \multicolumn{2}{c|}{ Marble aggregate } & \multicolumn{2}{c|}{ Granite aggregate } \\
\cline { 2 - 7 } & Mean* & Modified & Mean* & Modified & Mean* & Modified \\
\cline { 2 - 7 } 7 & & & & & & \\
14 & 138.34 & 134.19 & 190.32 & 184.61 & 196.71 & 190.81 \\
28 & 181.76 & 176.31 & 221.97 & 215.31 & 229.46 & 222.58 \\
70 & 199.44 & 193.46 & 270.15 & 262.05 & 280.55 & 272.13 \\
& 263.94 & 256.25 & 350.62 & 340.41 & 362.21 & 351.66 \\
& & & & & & \\
\hline
\end{tabular}

* Arithmetic mean of three tested cubes 


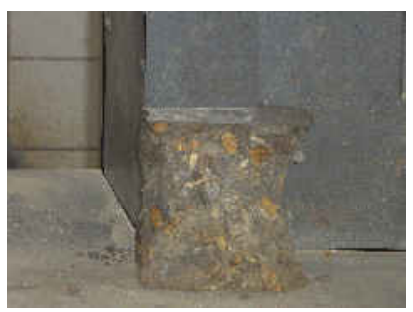

(a)

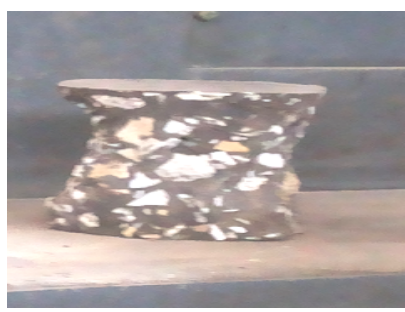

(b)

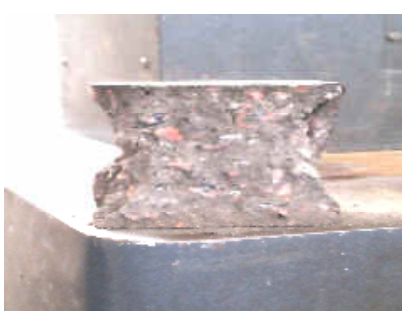

(c)

Fig. 2. Failure shape after compression test of cubes: (a) concretes of phosphate aggregate, (b) concretes of marble aggregate, (c) concrete of granite aggregate.

It is noticed from the results in Table 7 that the compressive strength of the concrete cubes made with phosphate aggregate is about $193.46 \mathrm{Kg} / \mathrm{cm}^{2}$ after 28 curing days, $262.05 \mathrm{Kg} / \mathrm{cm}^{2}$ for concrete cubes made with Marble aggregate and, $272.13 \mathrm{Kg} / \mathrm{cm}^{2}$ for concrete made with granite aggregate. The conventional concrete used in building may be of strength 175$300 \mathrm{Kg} / \mathrm{cm}^{2}$ [28]. This proves the possibility of use the three recycled aggregate as coarse aggregates in concrete production. The modified compressive strength after 28 days of curing increased with a value ranges from 29 to $31 \%$ than compressive strength after 7 days of curing.

Generally, the obtained compressive strength of the three types of recycled wastes is less than that of concrete produced from natural aggregate. This may be due to the higher content of silica in natural coarse aggregate (gravel) than that in the recycled aggregates. Also, the formation of micro cracks produced during crushing and screening operations of the recycled aggregates affect the properties of the produced concrete.

To achieve higher compressive strength of the three types of recycled aggregates, it is recommended to change the mix design, use a suitable type of admixture to concrete mix, use suitable w/c ratio, and finally improving the compaction of fresh concrete. For these points, further studies should be carried out

The strength of concrete made with natural aggregates increased with time until the age of ten years under normal temperature and humidity conditions. The empirical relationship between compressive strength of concrete cubes after 28 days of curing and curing time in range of 3 to 365 days was given by equation 1 .

$$
f_{C T}=0.7 f_{c 28} \times \log T
$$

Where $\quad f_{C T}$ : is the standard cube compressive strength after age $\mathrm{T}$,

$f_{c 28}$ : is the standard cube compressive strength after 28 days,

$\mathrm{T}:$ is the age in days.

Figure 3 illustrates the relation between the compressive strength (modified value) given in Table 7 and its age in log days for various concrete produced from the recycled aggregates and illustrate their predicted values of compressive strength using equation (1). Also it is clear from Figure 3 that the measured and predicted curves are approximately in the same trend with small difference in-between . 


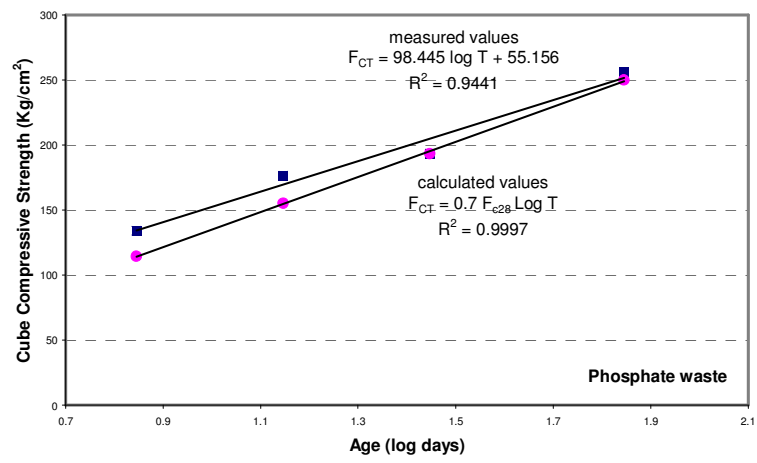

(a)

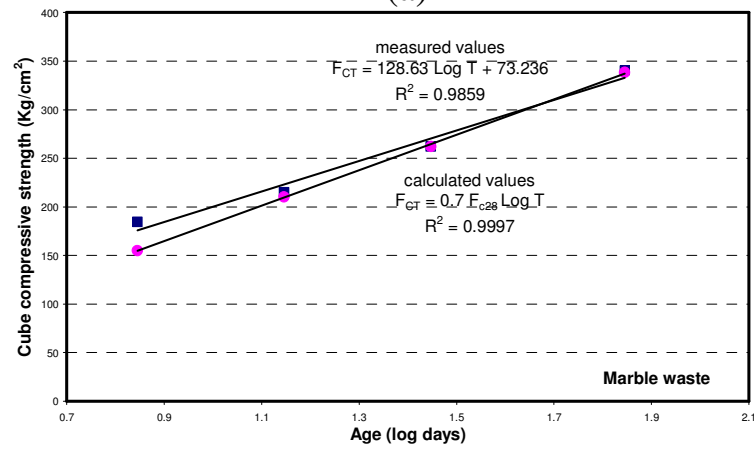

(b)

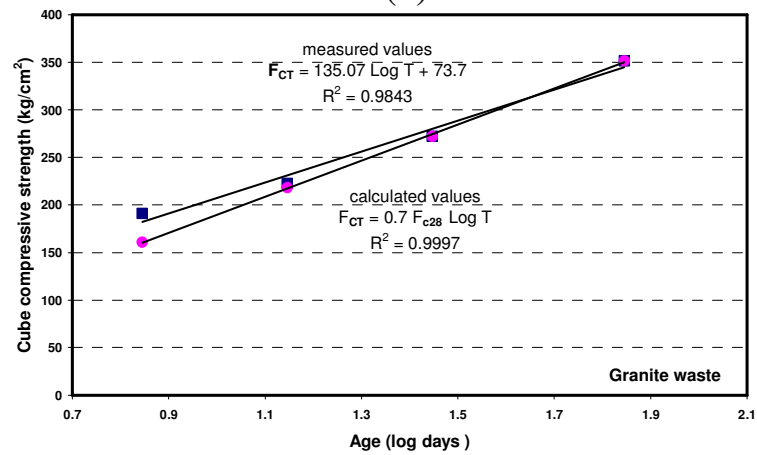

(c)

Fig. 3. The relation between the measured compressive strength of various concrete mixes using age in days, and the predicted values calculated by equation 1, (a) phosphate waste, (b)marble waste, (c) granite waste.

Flexural strength results: This test is used as an indirect tensile strength test. It is a measure of plain concrete beam or slab to resist failure in bending. Table 8 summarized the results of flexural strength test of $10 * 10 * 50$ beams for the three recycled aggregates samples after 28 days curing period. The test was conducted by two methods, using simple beam with centre-point loading or two third-points loading. In the centre-point loading the maximum tensile force is concentrated at a single point, whereas in third-point loading it is distributed to the length between the two loading points. In this study six beams of $10 * 10 * 50 \mathrm{~cm}$ were tested by the two methods for more accurate results and to find the 
correlation between the two methods. The test procedure is given in details in reference $[17,18$, and 28].

\section{Table 8.}

Results of flexural strength test of various concrete specimens.

\begin{tabular}{|l|c|c|c|}
\hline $\begin{array}{c}\text { Type of } \\
\text { recycled aggregate }\end{array}$ & $\begin{array}{c}\text { Two Third- point } \\
\text { loading, }\left(\mathrm{kg} / \mathrm{cm}^{2}\right)^{*}\end{array}$ & $\begin{array}{c}\text { Center- point loading } \\
\left(\mathrm{kg} / \mathrm{cm}^{2}\right)^{*}\end{array}$ & $\left(\mathrm{~F}_{\text {third }} / \mathrm{F}_{\text {center }}\right)$ \\
\hline Phosphate & 38.73 & 45.47 & 0.85 \\
Marble & 43.71 & 52.24 & 0.84 \\
Granite & 45.74 & 54.46 & 0.84 \\
\hline
\end{tabular}

* The arithmetic mean of the three beams tested.

The flexural strength $\left(\mathrm{F}_{\mathrm{cr}}\right)$ from two third point loading test is about 11-25\% from the standard cube compressive strength after 28 curing period $\left(\mathrm{F}_{\mathrm{c} 28}\right)$. Comparing the results in Table 8 with that given in Table 7 , its clear that the $\left(\mathrm{F}_{\mathrm{cr}} / \mathrm{F}_{\mathrm{c} 28}\right)$ is $20.02 \%$ for phosphate, $16.68 \%$ for marble and 16.81 for granite.

The flexural strength determined by two third-points loading is lower than flexural strength determined by center-point loading in the range of $15 \%$ to $16 \%$. The obtained results given in Table 8 prove this percent. Figure 4 shows the failure shape of beams in the two cases of loading.

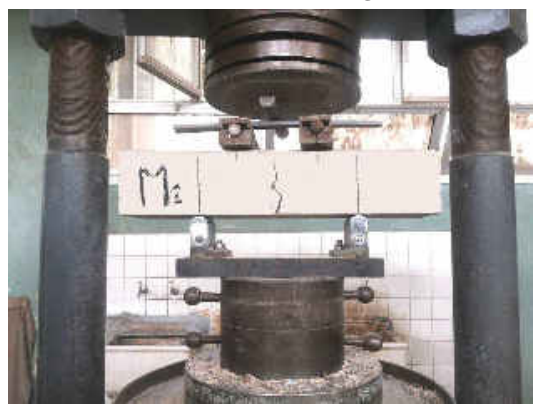

(a)

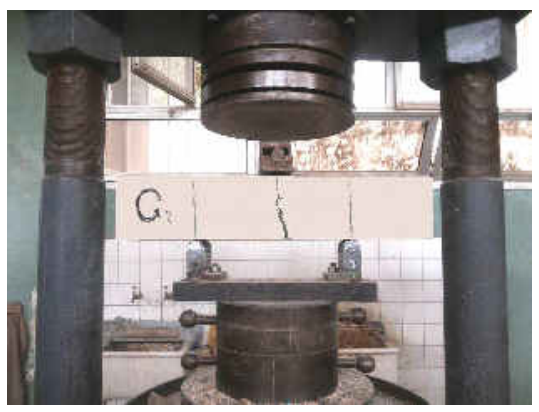

(b)

Fig. 4. The failure shape of beams in the two cases of loading, (a) Two third point loading, (b) center point loading.

\section{Conclusions}

From the results of the experimental work and their discussion, it can be concluded that:

- The physical, chemical and mechanical properties of the three waste materials used as coarse aggregate to substitute the natural gravel in concrete mixes are within the scope and requirements of ECP 203.

- Such kinds of solid wastes can be used in concrete mix without seriously hindering the mechanical properties of the produced concrete.

- The values of compressive strength of concrete cubes after 28 days of curing were found to be of the order of $193 \mathrm{Kg} / \mathrm{cm}^{2}, 262 \mathrm{Kg} / \mathrm{cm}^{2}$ and $272 \mathrm{Kg} / \mathrm{cm}^{2}$ with phosphate, marble, and granite aggregates respectively. 
- The use of such wastes as coarse aggregates is suitable for the construction of ordinary buildings in surrounding environment of mines and quarries.

- The overall test results revealed that the coarse aggregate of the three recycled waste materials can be utilized in concrete mixes as reasonable substitute of natural gravel.

- The convenient use of such solid wastes will render them as useful profitable products, natural resources will be conserved and environmental pollution will be reduced.

- Further studies should be carried out to improve the use of such wastes as coarse aggregates.

\section{REFERENCES}

[1] Pereira, C.G., Castro-Gomes, J. and Deoliveria, L.p.: "Influence of natural coarse aggregate size, mineralogy and water content on the permeability of structural concrete", Construction and Building Materials, Vol.23, pp.602-608, (2009).

[2] Castro-Gomes, J.p., Pereira, de Oliveira, L.p. and Gonilho- Pereira, C.N.:" Discussion of aggregate and water absorption and permeability testing methodology", XXXIAHS, world Congress on housing, Coimbra, Portugal, q-13 Sep., No.of p.8, (2002).

[3] Il-Seok, O.H.: "Effects of aggregates on the properties of concrete ", CE566B Term Project, Civil Engineering Department, Lowa State Univ., April 24, (2001).

[4] Binici, H., Shah, T., Aksogan, O. and Kaplan, H.:" Durability of concrete made with granite and marble as recycle aggregates ", J. of Materials Processing Technology, Vol.208, pp.299308, (2008).

[5] Sherwood, P.T.:" The utilization of mining and quarrying wastes in road construction", Land Reclamation Conference, pp.156-169, (1976).

[6] Yellishetty, M., Karpe, V., Reddy,E.H., Subhask, K.N.and Ranjith, P.G.: " Reuse of iron ore minerals waste in civil engineering constructions : A case study", Resources, Conservation and Recycling, Vol. 52, pp. 1283-1289, (2008).

[7] Mitchell, C.j., Horrison, D.j., Robinson, H.I. and Ghazireh, N.:" Mineral from waste: recent BGS and Taramac experience in finding uses for mine and quarry waste", Mineral engineering, Vol.17, pp.279-284, (2004).

[8] Hammond, A.A.:" Mining and quarrying wastes: A critical review Engineering geology, Vol.25, pp.17-31, (1988).

[9] Aljabo, A.A., Abd Elmoaty, A.M. and Auda, E.M.:" Re-use of waste marble dust in the production of cement and concrete", Construction and building materials, Vol.50, pp.28-41, (2014).

[10] Collings, R.K.:" Current and potential uses for mining and mineral processing wastes in Canada: Standards", J. of testing and Evaluation, Vol. 12, No.1, P.5, Jan.(1984).

[11] Al- Baijat, H.M.:" The use of basalt aggregates in concrete mixes in Jordan", Jordan Journal of Civil Engineering, Vol.2, No.2, No.1, pp. 63-70, (2008).

[12] Shehta.,I., Varzavand, S., Elsawy, A., and Fahmy, M.:" The use of solid waste materials as fine aggregate subistitutes in cementitious concrete composites", Transportation Conf., Iowa State Univ., No. of p.8, (1996).

[13] Ilongovana, R., Mahendrana, N., and Nagamanib, K. :" Strength and durability properties of concrete containing quarry rock dust as fine aggregates", ARPN Journal of Engineering and Applied Science, Vol.3,No.5,pp. 20-26, Oct. (2008).

[14] Celik, T. and Morar, K.:" Effect of crushed stone dust on some properties of concrete", Cement and Concrete Research, Vol.26, pp.1121-1130,(1996). 
[15] Jorge de Brito, A.A., and Diogo Pedro, A.R.:" Durability performance of concrete incorporating coarse aggregates from marble industry waste", Journal of Cleaner Production, No. of P. 8, (2013).

[16] Dhanapandian, S., Gnanavel, B. and Ramkumar, T.:" Utilization of granite and marble sawing powder wastes as brick materials ", Carpathian J. of Earth and Enironmental Science, Vol.4, No.2, pp.147-160, Oct.(2009).

[17] Megahid, A.A:" Design and Execution of concrete structures, Part II: plain concrete and its properties", No. of pages 352, (1999), in Arabic.

[18] Imam, M.:" Concrete- properties-quality- tests", No. of pages 246, (2002) ,in Arabic.

[19] Ahmed, A.A. and Abouzeid, A-Z.M.:" Utilization of coarse phosphate waste rejects as aggregates in concrete mix", Int. Seminar on Mineral Processing Tech.( MPT-2009), IMMT, Bhubaneswar, 28-30 Oct., (2009), India.

[20] Megahid, A.A.: " Concrete for engineers, Part I : its properties and manufacture", No. of pages 158, (1998) in Arabic.

[21] ECP 203 of concrete aggregates, No.1109, (1971), in Arabic.

[22] Abdulkareem, K.H.: "Preliminary lectures in properties and strength of building materials", p.147, (2004), in Arabic.

[23] Franklin, J.A., Dusseault, B.M.:" Rock Engineering", McGraw Hill Publishing Company, Tokyo, pp.43-46, (1989).

[24] Iorgal, F.P. and Castro-Gomes, J.P.:" Influence of physical and geometrical properties of granite and limestone aggregates on the durability of C20/C25 strength class concrete", Const. And Building materials, Vol.20, pp.1079-1088, (2006).

[25] ECP 203 of concrete tests, Part v, Methods of molding cubes from fresh concrete, No.1658, (1991) in Arabic.

[26] Kong, F.K., Evans, R.H.: "Reinforced and prestressed concrete", Published by Nelson, pp.17-19, (1976).

[27] Egyptian code of practice designs and execution of concrete structures, No.203, 2nd ed, (2008) in Arabic. 


\section{دراسه معمليه عن إمكانية إستخذام النفايات الصلبه \\ للمناجم والمحاجر فى انتاج خلطات الخرسانه}

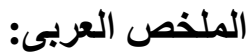

فى هذا البحث تم در اسة إمكانية إستغلال النفايات الصلبه الناتجه من تركيز خام فوسفات منطقة السباعية ـ

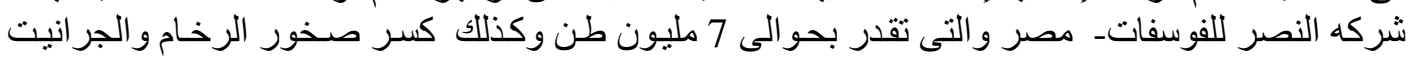

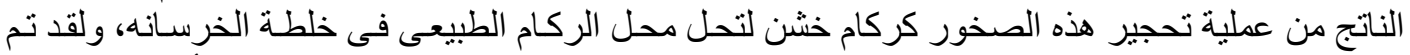

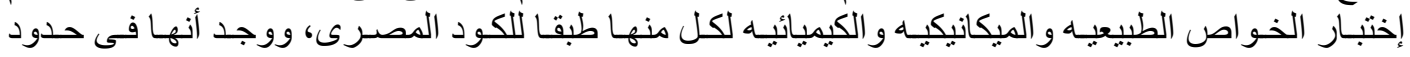

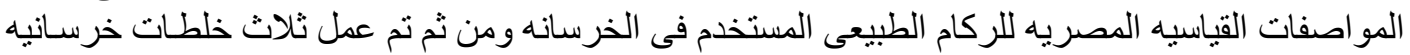

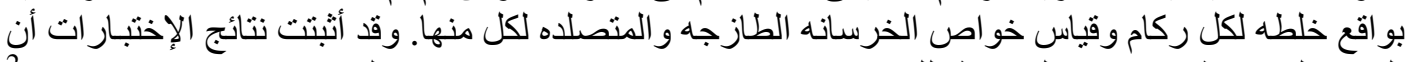

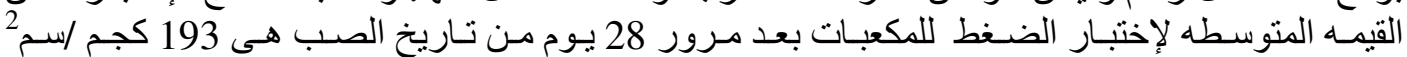

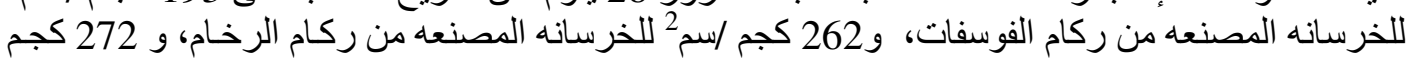

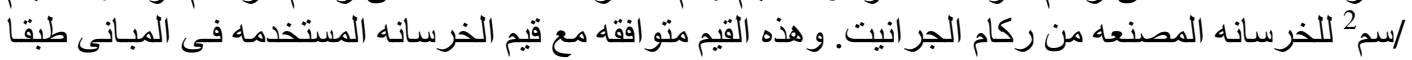

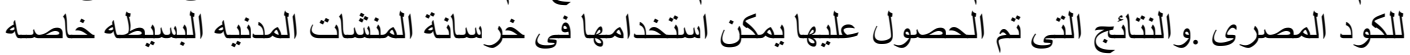

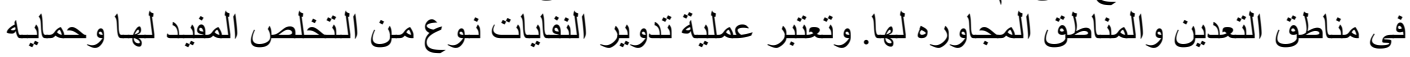

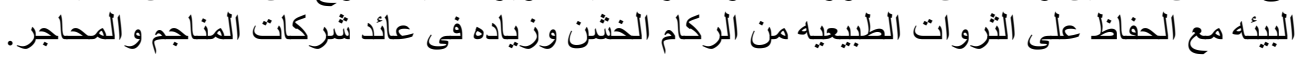

